\title{
Correspondence
}

\section{Lymphocyte subpopulations in essential mixed cryoglobulinaemia}

SIR, Essential mixed cryoglobulinaemia (EMC) is an uncommon disease characterised by the formation of cryoprecipitable complexes involving IgM and IgG. ${ }^{1}$ The IgM component can be monoclonal (type II cryoglobulinaemia) or polyclonal (type III cryoglobulinaemia) and displays an anti-Fc antibody activity comparable to rheumatoid factor. However, an idiotype-anti-idiotype reaction between IgM and IgG has been reported. ${ }^{2}$ Although hepatitis B virus (HBV) has been implicated in the aetiology of some cases of the disease,$^{34}$ little is known about its immunopathogenesis. The availability of monoclonal antibodies specifically directed against human lymphocytes and their subsets ${ }^{5}$ has provided a new tool for the analysis of $T$ cell and $B$ cell populations in human diseases. Recently, we investigated peripheral blood lymphocytes and the distribution of inducer-helper and suppressor-cytotoxic subsets in five patients with EMC.

Three men and two women, mean age 53 years (range 33-63), were investigated. All five patients had recurrent purpuric rash and two had arthralgia. Three patients had liver disease (Table 1, patients Nos 1, 2, and 3) and three had HBV serological markers in their serum (patients Nos 1,3 , and 4). At the time of the study none of the patients were receiving any treatment.

Lymphocytes were separated from heparinised whole blood by a density gradient technique (Ficoll-Hypaque). Monoclonal antibodies to all peripheral T cells (OKT3), to helper T cells (OKT4), to suppressor T cells (OKT8) (Ortho Diagnostics), and to B cells (B-1) (Coulter clone) were used, and cells numbers were assessed under fluorescence epi-illumination with a Dialux 20 EB Leitz microscope.

As shown in Table 1 the two patients with type II cryoglobulinaemia had high percentages of peripheral $\mathrm{T}$ cells $\left(\mathrm{OKT}^{+}\right)$and helper-inducer $\mathrm{T}$ cells $\left(\mathrm{OKT}^{+}\right)$, with nearly normal percentages of suppressor-cytotoxic $\mathrm{T}$ cells $\left(\mathrm{OKT}^{+}\right)$, and consequently a high ratio $\mathrm{OKT}_{4}^{+} /$ $\mathrm{OKT}^{+}$; while the three patients with type III cryoglobulinaemia had normal percentages of $\mathrm{OKT}^{+}$ $\mathrm{OKT}_{4}{ }^{+}$, and $\mathrm{OKT}^{+}$subsets of $\mathrm{T}$ lymphocytes. The percentage of $\mathrm{B}-1^{+}$cells was normal in all patients.

Our results are in disagreement with those reported by Meroni et al., ${ }^{6}$ which showed reduced percentages of $\mathrm{OKT}^{+}{ }^{+}$cells with a low ratio $\mathrm{OKT} 4^{+} / \mathrm{OKT}^{+}$in patients with EMC. Moreover, these investigators ${ }^{6-8}$ found evidence of in vitro abnormalities in the function of suppressor-cytotoxic T lymphocytes and B lymphocytes.

Our data are difficult to interpret, though they suggest the possibility that different immune derangements can occur in EMC according to the type (II to III) of the cryoglobulinaemia. Further studies are necessary on a greater number of patients.

$\begin{array}{lr}\text { Dept. of Internal } & \text { FERNANDo GARCía-BRAGADO DALMAU" } \\ \text { Medicine and } & \text { GEMMA ACEBEDO } \\ \text { Hematology Service, } & \text { MERCEDES BIOSCA } \\ \text { Hospital General } & \text { MARIA VILLAR } \\ \text { 'Valle Hebrón, } & \text { MIGUEL VILARDELL }\end{array}$

Universidad Autónoma

Barcelona 08035,

Barcelona,

Spain

- Correspondence to Dr F G-B Dalmau, Calle Tenor Viñas no 1, Pral. $1^{\mathrm{a}}$, 08021-Barcelona, Spain.

\section{References}

1 Meltzer M, Franklin E C, Elias K, McCluskey R T, Cooper N. Cryoglobulinemia: a clinical and laboratory study. II Cryoglobulins with rheumatoid factor activity. Am J Med 1966; 40: 837-56.

2 Geltner D, Franklin E C, Frangione B. Antiidiotypic activity in the IgM fractions of mixed cryoglobulins. J Immunol 1980; 125: 1530-5.

Table 1 Lymphocyte subpopulations in patients with essential mixed cryoglobulinaemia

\begin{tabular}{|c|c|c|c|c|c|c|c|c|}
\hline \multirow[t]{2}{*}{ Patient No } & \multirow[t]{2}{*}{ Sex } & \multirow{2}{*}{$\begin{array}{l}\text { Age } \\
\text { (years) }\end{array}$} & \multirow[t]{2}{*}{ Cryoglobulinaemia type } & \multicolumn{5}{|c|}{ Reactivity with monoclonal antibodies to: } \\
\hline & & & & $\begin{array}{l}O K T 3^{+} \\
(\% \text { of } p\end{array}$ & $\begin{array}{l}\text { OKT4 } \\
\text { sitive cells) }\end{array}$ & $O K T 8^{+}$ & $B-1^{+}$ & $\begin{array}{l}\text { OKT4 } \\
\text { Ratio }\end{array}$ \\
\hline 1 & $\mathbf{F}$ & 60 & Type II IgMk-IgG & 90 & 68 & 15 & 6 & $4 \cdot 5$ \\
\hline 2 & $\mathbf{F}$ & 57 & Type II IgMk-IgG & 92 & 65 & 20 & 8 & $3 \cdot 2$ \\
\hline 3 & $\mathbf{M}$ & 33 & Type III IgM-IgG & 74 & 52 & 29 & 10 & $1 \cdot 7$ \\
\hline 4 & $\mathbf{M}$ & 52 & Type III IgM-IgG & 65 & 48 & 20 & 11 & $2 \cdot 4$ \\
\hline 5 & $\mathbf{M}$ & 63 & Type III IgM-IgG & 70 & 57 & 28 & 8 & 2 \\
\hline $\begin{array}{l}\text { Normal values in } 10 \text { adults } \\
\text { (range) }\end{array}$ & & & & $59-83$ & $32-61$ & $16-32$ & $7-17$ & $1 \cdot 2-2 \cdot 9$ \\
\hline
\end{tabular}


3 Levo Y, Gorevic P D, Kassab H J, Zucker-Franklin D, Franklin E C. Association between hepatitis B virus and essential mixed cryoglobulinemia. $N$ Engl J Med 1977; 296: 1501-4.

4 García-Bragado F, Villar M, Biosca M, Vilardell M, Jardi R, Allende E. Essential mixed cryoglobulinemia and chronic persistent hepatitis. $N$ Engl J Med 1985; 312: 187.

5 Reinherz E L, Schlossman S F. Regulation of the immune response inducer and suppressor T-lymphocyte subsets in human beings. $N$ Engl $J$ Med 1980; 303: 370-3.

6 Meroni P L, Barcellini W, De Bartolo G, Invernizzi F, Zanussi $\mathrm{Z}$. Abnormalities of in vitro immunoglobulin synthesis by peripheral blood lymphocytes from patients with essential mixed cryoglobulinemia. Clin Immunol Immunopathol 1984; 33: $245-57$.

7 Meroni P L, Ciboddo G F, Colombo G, Bonara P, Invernizzi F. T Cell defect in essential mixed cryoglobulinemia. Int Arch Allergy Appl Immunol 1979; 59: 308-14.

8 Meroni P L, Barcellini W, Messina K, De Bartolo G, Capsoni F, Invernizzi F. Defective suppressor cell activity in essential mixed cryoglobulinemia. J Clin Lab Immunol 1982; 8: 177-82.

\section{Systemic lupus erythematosus without clinical renal abnormalities}

SIR, We read with interest the study of O'Dell et al ${ }^{1}$ showing a high incidence of mesangial changes in renal biopsies from patients with systemic lupus erythematosus (SLE) without clinical renal abnormalities. They found no cases of focal or diffuse proliferative glomerulonephritis. These results are different from those previously reported by other authors ${ }^{23}$ and question the relevance of renal biopsy in these patients.

Recently we have performed renal biopsy in 13 patients with SLE (fulfilling the American Rheumatism Association revised criteria ${ }^{4}$ ) who had no clinical signs of renal involvement (no urinary sediment abnormalities, absence of proteinuria, and serum creatinine below $1.3 \mathrm{mg} / \mathrm{dl}(115$ $\mu \mathrm{mol} / \mathrm{l})$ ). All renal biopsy specimens were examined by two pathologists and categorised according to the modified classification proposed by the World Health Organisation. $^{5}$

Five cases $(38 \%)$ showed no histological or immunofluorescence changes (type I), six (46\%) patients had a mesangial nephropathy (three type IIa and three type IIb), and two $(15 \%)$ had a focal proliferative glomerulonephritis (type III). None of the patients had previous evidence of neurological abnormalities. Patients with normal renal biopsies (type I) only had arthritis, skin lesions, and Raynaud's phenomenon. In contrast, six patients with histological renal involvement had serositis or haemolytic anaemia. All cases with silent nephropathy were treated with steroids and showed a benign clinical course with stable renal function and absence of urinary abnormalities during follow up (one to 76 months, mean 27 months).

On the basis of these results we agree with O'Dell $e a^{\prime}{ }^{1}$ that, in the absence of clinical renal abnormalities, significant renal involvement is uncommon in SLE. However, as reported by Mahajan et $a l^{2}$ and Lehey et $a l^{3}$ and confirmed in the present study, a few patients may $\frac{}{\omega}$. have severe renal lesions requiring steroid therapy. Thus until more information becomes available we believe that a renal biopsy should be performed in those SLE patients presenting with clinical manifestations other than arthritis or cutaneous lesions since this policy may allow detection of silent nephritis lesions.

Servicio de Medicina Interna,

Hospital Clínico y Provincial,

Facultad de Medicina,

Barcelona, Spain

Servicio de Nefrologia,

Hospital Clínico y Provincial,

Facultad de Medicina,

Barcelona, Spain

\section{References}

1 O'Dell J R, Hays R C, Guggenheim S J, Steigerwald J C. O Systemic lupus erythematosus without clinical renal abnormalities: renal biopsy findings and clinical course. Ann Rheum Dis 1985; 44: 415-9.

2 Mahajan S K, Ordoñez N G, Feitelson P J, Lim V S, Spargo B H, Katz A L. Lupus nephropathy without clinical renal involvement. Medicine (Baltimore) 1977; 56: 493-501.

3 Leehey D J, Katz A I, Azaran A H, Aronson A J, Spargo B H. Silent diffuse lupus nephritis: long-term follow up. Am J Kidney Dis 1982; 2 (suppl 1): 188-96.

4 Tam E M, Cohen A S, Fries J, et al. The 1982 revised criteria for the classification of systemic lupus erythematosus. Arthritis Rheum 1982; 25: 1271-7.

5 Finlander P, Koss M, Kitridou R, Border W A. Glomerulonephritis in systemic lupus erythematosus. Am J Nephrol 1981; 1: 53-67.

SIR, We appreciated the letter of Font et al and the opportunity to respond to it. The findings of Font $e t$ al that none of the 13 lupus patients without clinical evidence of renal disease had diffuse proliferative glomerulonephritis are very similar to our findings but very different from the findings of Mahajan et al. ${ }^{1}$ We were surprised that five of $\frac{5}{3}$ the 13 lupus patients in their study (Font et al) had completely normal renal biopsies. All of our patients, $ᄋ$ despite the absence of clinical renal abnormalities, had mesangial abnormalities as shown either by light micro- 0 scopy or by immunofluorescence studies. Our findings are similar to those of most other studies published in the literature, which show that most patients, despite the absence of clinical renal disease, have abnormalities on $\mathrm{N}$ renal biopsies. ${ }^{1-4}$

We do not agree with the recommendation of Font et al that because they found focal proliferative glomeru- $\underset{\omega}{ }$ lonephritis in two of their patients they would advocate 0 renal biopsies in lupus patients in the absence of clinical renal abnormalities. As stated in our paper there is no evidence in the literature to suggest that early treatment of $\stackrel{5}{\rightarrow}$ histopathological abnormalities found on renal biopsy in the absence of clinical findings will in any way influence -0 prognosis. In fact, all studies in lupus nephritis that have $\overrightarrow{\mathbb{D}}$ looked at the question have concluded that clinical $\stackrel{9}{?}$ parameters are a much stronger indication of prognosis $\underset{Q}{\mathbb{Q}}$ than histological classification. 